\title{
Education unbound? Enlivening debates with a mobilities perspective on learning
}

\begin{abstract}
This paper contributes to recent debates on the geographies of education. I argue that research in geography on education over the past decade has conceptualised education principally in terms of attachment to - and boundedness within - particular (often institutional) places and spaces. Yet a productive tension has emerged in contemporary scholarship around the competing concepts of mobilities and emplacement. The paper considers what the 'mobilities turn' offers for understanding the geographies of education and our understanding of education and learning, with a focus on ripple effects, structures and subject positionings. Four different but related bodies of work are identified that productively engage a notion of 'mobilities' to challenge bounded conceptions of education through their focus on i) community and mobility; ii) 'alternative' spaces of education; iii) student mobilities; and iv) embedded institutional capital and internationalisation. Through the lens of mobilities, the paper advances research agendas within both geography (on 'geographies of education') and cognate disciplines (such as sociology and education).
\end{abstract}

Key words: geographies of education institutions embeddedness mobilities 


\section{Introduction}

There is an intriguing tension emerging between work on mobilities in education and the need to place, ground and delimit educational spaces. In much contemporary debate, education continues to be primarily associated with particular institutions and spatial arrangements, such as classrooms, lunch halls, playgrounds, university campuses, lecture theatres and libraries (Cook and Hemming, 2011). These sites have long represented archetypal educational spaces - widely recognisable places where formal education is enacted and learning occurs. However, a more recent interest amongst scholars in mobilities, in their varied forms, has sought to decentre the institutional, place-based bias in educational research, and has encouraged a consideration of other (more spatially contingent) ways of conceptualising education and learning (see Kraftl, 2015, for a discussion of the spatial implications of 'de-schooling'). This focus is part of a vibrant 'educational turn' within human geography, characterised by a resurgence of interest in geographies and spatialities of education over the past ten years (Brooks and Waters, 2011; Cheng, 2015; Collins, 2012; Hanson Thiem, 2009; Holloway and Jöns, 2012; Thieme, 2014; Waters, 2006a, 2006b, 2007, 2008).

This paper considers the ways in which the concept of 'mobilities' can enhance our understanding of the geographies of education. Specifically, it highlights the contribution of scholarship that has taken seriously the relationship between the emplacement of education, on the one hand, and mobilities on the other. Here, I suggest that an appreciation of diverse mobilities in education can significantly enliven debates and advance research agendas within and beyond the discipline of geography. The 'mobilities turn', as it has been known in the social sciences (see Urry, 2000), has important implications for understanding the relationship between individual agency and various structures in education. As a concept, 'mobilities' necessitates thinking relationally and contextually about educational processes 
and the interplay of structure/fixity and agency/flows. Prominent examples of structures in respect of education might be class structures, for example, or state (national) structures. Agency, on the other hand, refers to the tendency in much recent writing around education to individualise 'choice' in education and valorise unfettered spatial movements (travel). In this paper, I attempt to draw out from various work on mobilities in education the crucial and necessary interplay between structures/agency and fixity/flows.

Within the increasingly substantial literature on 'geographies of education' that has come to prominence over the past decade, a mobilities perspective is both implicitly and explicitly present. I have grouped this work into four themes. These are: i) community and mobility; ii) 'alternative' spaces of education; iii) student mobilities; and iv) embedded institutional capital and internationalisation. What unites the work reviewed here is an attempt to conceptualise mobility as a fundamental aspect of education - as somehow integral to the 'learning experience' (very broadly defined), and not as something that deflects from or merely impacts upon learning. Scholarship in this area remains relatively nascent, but represents an opportunity for human geographers to continue to shape emergent debates beyond the discipline around education, space and place (see Gulson and Symes, 2007; Brooks and Waters, forthcoming).

Here, I begin with an overview of recent research on geographies of education, identifying some prevalent themes. The paper then grapples with what I have identified as an apparent tension between the importance of place (embeddedness) in education and a growing tendency to highlight mobilities. The main body of the paper illustrates how particular authors have dealt with this tension, through exploring the relationship between 'education as place' and 'education as mobilities'. This tension is productive, in that it opens up new ways of seeing education (as primarily a relational and spatially contingent practice) and new possibilities for work around education (that foreground mobilities). In conclusion, I 
reflect upon what this emergent body of work contributes to debates around geographies of education and also to discussions external to the discipline on (in particular the sociologies of) education and learning.

\section{Geographies of education}

In a relatively short space of time, research on different aspects of education in geography has proliferated, and interest in this area continues to grow. A focus upon education, more generally, can be found within some recent special issues of disciplinary journals, for example in: Social and Cultural Geography (2011) on 'education spaces'; Children's Geographies (2011) on 'geographies of education and aspiration'; Globalisation, Education and Societies (2011) on 'transnational/international spaces of education'; a virtual issue of Transactions of the Institute of British Geographers (2012), which focused on 'geographies of education and learning' (edited by Holloway and Jöns); and an issue on 'youth migration and spaces of education' in Children's Geographies (2014). There have been some key papers, too, outlining research agendas in this area - including Hanson Thiem's essay in Progress in Human Geography in 2009 and Holloway, Hubbard, Jöns and Pimlott-Wilson's paper in 2010, also in Progress in Human Geography, on 'geographies of education and the significance of children, youth and families'. Madge et al. (2014) recently contributed to debates with a piece on international students and international study (see also Raghuram, 2013), and Craig Jeffrey's work combines a substantial literature on 'youth' and 'young people' with empirically rich and theoretically sophisticated scholarship on education and labour markets in India (e.g. Jeffrey 2008, 2010). 
Through their review of recent literature ${ }^{1}$, Holloway and Jöns (2012) go as far as to identify:

\begin{abstract}
'a body of work that can justifiably be labelled 'new geographies of education and learning' because it is intra- and inter- disciplinary as well as increasingly international in terms of knowledge producers and sites of study' (p. 485).
\end{abstract}

This is a bold statement that underlines the significance of recent scholarship on geography and education. Holloway and Jöns (2012) highlight the disciplinary multiplicity on display; the way in which research in geography on education cross-cuts social, cultural, economic and political sub-disciplines, as well as demonstrating geographical diversity in terms of where knowledge in this area is being produced (for example, in East and Southeast Asia as well as in North America, Western Europe and Australasia). ${ }^{2}$ In other ways, too, a sub-field of 'new geographies of education' is being demarcated. The First (2009) and Second (2012) International Conferences on Geographies of Education held at Loughborough University in the U.K. were extremely successful, well attended events, with another one in the planning. Elsewhere, Singapore (NUS Geography) has been home to a large research project examining the globalisation of universities and the international mobilities of students (2009-2012), funded by the Singapore Ministry of Education and comprising an international team of researchers from Australia, New Zealand, Japan, Taiwan, Singapore and Korea (e.g. Collins et al, 2014). In the United States (University of Illinois), Abelmann (e.g. 2009) has included

\footnotetext{
${ }^{1}$ They reviewed published papers for a special virtual issue of Transactions of the Institute of British Geographers. The oldest paper selected was published in 2006.

${ }^{2}$ There is, as one reviewer pointed out, an English-language bias in much of this work around mobilities. This possibly reflects, in part, a global publishing culture where English-language publications are most valued.
} 
geographers in her recent transnational project seeking to understand South Korean educational mobilities. These are just a few examples of large initiatives in the area of geographies of education.

There has also been some interest from outside the discipline in the spatial aspects of education. Some synergies between geographers and non-geographers are emerging, as evidenced in a number of joint publications, research projects and seminars (e.g. Brooks and Waters, 2011; Brooks et al. 2012; Kraftl et al., 2013). Olds (geographer based in the U.S.) and Susan Robertson (sociologist based in the U.K.), for example, have been extremely active in editing and contributing to their Global HE blog (https://globalhighered.wordpress.com/about/) transnationally, as well as teaching a MOOC on 'Global higher education and research for the 'knowledge economy'.

If we focus, however, specifically on the work of geographers, we see some interesting diversity in topics and subject areas, as well as in underlying methodologies. A fairly cursory examination of some 'key' geographical journals shows a number of prevalent themes. More traditional topics around education that continue to attract interest include: travel to school (Ferrari and Green, 2013; Pooley et al., 2010; Wilson et al., 2010), school choice (Butler and Hamnett, 2010; Taylor, 2001; Wilson et al., 2010), social segregation (and links to educational performance) (Johnston et al., 2007; Harris, 2012; Herbert and Thomas, 1998; Warrington, 2005), and school location and neighbourhood effects on educational outcomes (Gibson and Asthana, 1998a, 1998b; Nieuwenhuis et al., 2013; Sykes and Kuyper, 2009). These topics often (but not always) lend themselves to more quantitative forms of analysis (such as the use of indices of segregation and separation, GIS, or large data sets). In contrast, a significant number of qualitative researchers have explored small-scale, quotidian education-related interactions - within classrooms, school dining halls, on playgrounds and on university campuses (e.g. Andersson et al, 2012; Barker et al., 2010; Brooks et al., 2015; 
Holt, 2003; Kraftl, 2006; Pike and Colquhoun, 2012; Reh et al., 2011; Turner and Manderson, 2007). There is little doubt that, taken as a whole, work on 'geographies of education' is thriving. The breadth and depth of scholarship in this area, today, contrasts markedly with the situation a decade ago, when education was very much of peripheral interest to the wider geographical community.

In this paper, however, I focus upon the development of work in areas where geographers are providing a particular contribution to debates on education - debates which often have a strong foothold in other disciplinary areas (such as sociology). These areas are: community and mobility, research around alternative education, interest in student mobilities, and internationalisation and institutional capital. In different ways, this work challenges the 'institutional bias' found within research on education. These debates necessitate a revaluation of the interrelationship between space and learning. The specific focus of this paper hints at a bigger, nascent project - to elucidate, theoretically and empirically, the relationship between place, space and education. Interest from outside the discipline (from individuals with a sociological or education background) has perhaps given more urgency to the claim that human geographers should be well placed to provide critical commentary upon these issues, and yet have been generally slow to do so (Hanson Thiem, 2009). Attesting to this, Ferrare and Apple (2010) made the following assertions in their paper on the need to 'spatialise' education:

'Recently there has been increasing interest in the notion that 'space matters' among sociologists, psychologists, historians and educationalists. What was once the exclusive domain of geographers has now become the intellectual terrain across a broad spectrum of social science disciplines.' (p. 209) 
With this broader intellectual context in mind, in the next section I explore the ways in which education has been seen to be wedded to particular institutional spaces, and suggest the limits that this perspective places on our ability to understand the geographies of education.

\section{III.Education and institutional spaces}

Collins and Coleman (2008) write: 'Schools ... are one of the few institutions that can be found in almost every urban and suburban neighbourhood and with which almost every individual has meaningful, sustained contact at one or more points in their lives' (p. 281, emphases in original). They are ubiquitous, pervasive and unavoidable entities. Schools are also distinctive places - 'a bounded portion of geographical space within which certain rules apply and particular activities occur' (Collins and Coleman, 2008, p. 282; see also Barker et al., 2010; Waters and Brooks, 2015). Little wonder, then, that scholarship on education has for so long prioritised the school as a unit of study and that the focus of much research on education concerns the learning that occurs within the four walls of the classroom or lecture theatre, confined to the school ground or university campus.

A number of studies have drawn upon the ideas of Foucault when theorising children's experiences of school spaces (Barker et al., 2010; Pike and Colquhoun, 2012) and there is some overlap, here, with institutional geographies literatures (Philo and Parr, 2000). Discipline, surveillance, and control of children's behaviour are overarching themes in much of this work on school spaces. For example, Barker et al. (2010) discuss the rise of schoolbased 'exclusion units' - new school spaces where pupils excluded from normal classroom activities are housed as a punishment for misdemeanours. Another paper describes how the spatial layout of the dining hall in four primary schools in England encourages healthy eating behaviours but discourages social interaction, applying in the analysis Foucault's notion of governmentality (Pike and Colquhoun, 2012). There have been several interesting studies 
involving playgrounds, contemplating the link between how space is ordered in/through playgrounds, and consequent social (inter)actions (e.g. Holt, 2003, 2007; Thomson, 2005). These often speak to wider societal issues, such as Holt's (2007) work on the inclusion of disabled children into 'mainstream' schooling, the relationship between children's everyday sociospatial practices and the reproduction of dominant discourses around (dis)ability, and playground interactions (Holt, 2007). As these few examples help to illustrate, the site of the school has provided and continues to provide a useful 'container' of social practices and a helpful and productive means of delimiting research parameters on education and geography. Other, related work has used the university campus similarly to interrogate the socio-spatial relations underpinning students' lives (Andersson et al. 2012; Brooks et al. 2015; Leung and Waters, 2013; Turner and Manderson, 2007).

Inevitably, however, there are disadvantages attendant with a place-based view of education and the understanding of learning that it can provide. As identified by Holloway and Jöns (2012), learning spaces are not discrete entities but are increasingly porous in nature:

'Educational institutions are constituted by complex networks that are created and maintained by incoming and outgoing mobility of its students and staff, and by diverse flows of knowledge, information, capital and resources' (p. 485).

Here the significance of mobility is stressed. Contrary to Goffman's (1961) conceptualisation of the 'total institution', schools are impacted and inflected by movements of varying kinds,

\footnotetext{
3 'A total institution may be defined as a place of residence and work where a large number of like-situated individuals, cut off from the wider society for an appreciable period of time, together lead an enclosed, formally administered round of life' (Goffman, 1961, p.11).
} 
not least (and most straightforwardly) by the inflows and outflows of staff and pupils on a daily basis. Perhaps more abstractly, it is necessary also to consider the various assemblages of things (books and other learning materials, buildings, furniture, technology, and so on) that schools represent, and how things come to be combined, united and disconnected within and beyond the space of the school, and how, indeed, they come to constitute 'the school' as a unitary notion (Brooks and Waters, forthcoming).

Other research over the past few years has attempted to expand the spatial scope of studies of educational spaces, by including, for example, the 'home, pre-school, neighbourhood, after-school' (Holloway et al. 2010, p. 595) and so on into geographies of education. This view helpfully asserts that learning occurs in diverse spaces (and at stages across the life course) (see Brooks et al. 2012). Recent work on homeschooling and other forms of 'alternative' education, as discussed below, has perhaps been most instrumental in highlighting the complexity of where education is located and why (Kraftl, 2013a, 2013b).

However, acknowledging the geographical diversity of educational spaces (as these studies do) still does not fundamentally challenge the notion of spatial 'containers' of learning (Kraftl, 2012; see also Brooks et al., 2012). Taking a further step towards 'decentring' educational research, in this paper I explore the idea that education spaces may not only be porous and indistinct, but may themselves be mobile, and not simply impacted by mobility. At the same time, it is necessary to recognise that learning is grounded, emplaced, and dependent upon various materially embedded assemblages of people and things. ${ }^{4}$ It is to the issue of mobilities and education that the paper now turns.

\section{IV.Mobilities and education}

\footnotetext{
${ }^{4}$ In other areas, geographers have been instrumental in 'grounding' otherwise rather abstract discussions around globalisation, internationalisation and population mobility - see for example, Ley (2010).
} 
A consensus has emerged within the social sciences around the significance of mobility to everyday life. Hitherto, it has been claimed, scholars have treated mobility as a form of 'deviance' - an aberration or temporary interruption of the social equilibrium (Cresswell, 2006; Sheller and Urry, 2006; Urry, 2000). The past fifteen years, however, has witnessed a significant shift in the way in which mobility is perceived. According to Cresswell $(2006$, p. 1) it is now recognised that 'mobility is central to what it means to be human'. Consequently, the concept of 'mobilities' (or 'mobility') in human geography has impacted many areas of study, including education.

Scholarship on mobilities in education and learning has focussed on the mobility of people (such as students/pupils, academics, parents, teachers and families) (Ackers and Gill, 2009; Alberts and Hazen, 2013; Jöns, 2007; Leung, 2013; Waters, 2006a, 2008), the shifting landscapes of education policies and policy mobilities (Ball, 2016; Geddie, 2014; McCann, 2011; Peck, 2011; Rizvi and Lingard, 2010; Sidhu, 2006), the mobility of academic institutions (such as found in transnational education or TNE and the growth in off-shore campuses) (e.g. Geddie, 2012; Leung and Waters, 2013; Waters and Leung, 2013), and the mobility of ideas and pedagogy (Apple et al., 2005; Williams, 2007).

Work on student (im)mobilities is increasingly proliferous (Brooks and Waters, 2011; Hinton, 2011; Holdsworth, 2009a, 2009b; Holdsworth, 2013), and includes mobilities at different scales: from localised patterns around school choice (at primary and secondary levels), to the national mobility of university students 'leaving home', to the international movements of millions of non-resident students. A 'classic' and much cited paper on local school mobilities by Ball et al. (1995) depicts class-based patterns of educational choice within London. Class position is identified as the central and deciding factor when it comes to understanding mobility at secondary-school level - working class families are described, revealingly, as 'locals', whereas middle-class families are (conversely) 'cosmopolitans'. 
Ultimately, the paper argues, middle-class families are willing and able to travel significant distances away from home to access educational opportunities, in a way that working-class families are not. In a related vein although with respect to higher education, Holdsworth (2009a, 2009b) has undertaken research on UK university attendance and the notion of 'leaving home'. In the context of changes to higher education (HE) policies and debates around tuition fee increases during the early 2000s, Holdsworth analysed admissions data for UK universities and showed that the expansion of HE in the UK has coincided with a reduction in interregional student mobility. And yet, despite proportionately fewer students attending universities 'away from home', expectations around 'moving away' have continued to shape students' experiences of HE (Holdsworth 2009a; see also Christie 2007). Holdsworth writes:

'The social meanings of student mobility [opportunities for freedom and independence] are interwoven not only into accounts of university experiences given by students, but continue to govern HE recruitment strategies and the delivery both of academic courses and of pastoral support [...] The interview data illustrate how the experiences of becoming independent and of being more responsible are recognised and celebrated by students who move, yet are not restricted to this group and are not denied to students who stay. Mobility is not a necessary condition of negotiating transitions to adulthood, particularly for learning about responsibilities, though it is often assumed to be the case. Rather, in celebrating students' mobility we are valorising a particular model of transition to adulthood which focuses on separation, self-reliance, and responsibility for the self, rather than one based on interdependencies, mutual support, and responsibility for others' (1861). 
In this, Holdsworth provides a wonderful demonstration of the relational nature (ripple effects) of (higher) education, and how non-movers' experiences implicate, in fundamental ways, significant others.

There is also now a growing literature on the international mobilities of students, particularly at tertiary level but also at lower levels of schooling (primary and secondary-aged children, where the focus is very much centred on East and Southeast Asia). This is diverse and expansive, so I will focus briefly here only on a small number of notable contributions made by geographers. One of the central tenets of this work is that mobility is fundamental to the experience of (international) education. Simply put, students accrue what has been termed 'mobility capital' (Murphy-Lejeune, 2004) by going abroad for education (see Findlay et al., 2006, 2012; King and Ruiz-Gelices, 2003; Waters, 2006a). They attain a whole variety of embodied and institutionalised cultural capital (including language skills, humour and comportment) that can be exchanged, more or less directly, for economic capital, in the labour market. Conversely, students are significantly disadvantaged in cases where foreign credentials are acquired 'in situ', without attendant mobility, as one recent project on transnational education (TNE) and immobility in Hong Kong has shown (Waters and Leung, 2013). Mobility (being 'out of place') is also fundamental to international students' quotidian experiences, particular those that revolve around aspects of culture (Collins, 2008, 2010; Ghosh and Wang, 2003), racism (Alberts and Hazen 2005; Collins 2006, 2010; Park 2010), and gender (Holloway et al., 2012, Walton-Roberts, 2015).

In contemplating the contribution that a 'mobilities' perspective could make to contemporary debates around education, I wish to posit a number of questions. These questions arise from an appreciation of the impact that a 'mobilities turn' has had within the social sciences; at their core is the interplay of structures and flows. Adey (2010) talks about the importance of understanding mobilities relationally, and how mobilities elicit a 'ripple 
effect'. A first question therefore concerns the ripple effects of education: how does one person's mobilities for education impact upon and affect others? Another implication of the relationship between structures and flows concerns the physical 'moorings' associated with education: 'The complex mobilities of social life require being placed in relation to immobilities...moorings that are solid, static and immobile' (Adey, 2010, p. 20). A second question, then, concerns identifying what are the fixed structures that enable/restrict and are impacted by educational mobilities (see Brooks and Waters, forthcoming for further elaboration on this point). The literature would suggest two key 'structures' pertinent to this debate: class structures (after Bourdieu), and state structures (e.g. immigration regulation). A sub-set of this larger question might concern the barriers (physical or metaphorical) that students face that impact upon or are impacted by their mobilities. A third contribution of the mobilities turn relates to the 'fixed' and 'fluid' positionings of subjects (Adey, 2010, p. 25), and the question that arises from this observation might be: how do students negotiate various subject positionings as a consequence of their (im)mobilities? In what follows, the paper draws upon the recent literature to address these three conceptual questions, summarised as i) ripple effects (of education); ii) fixed structures (affecting education) and iii) (student) subject positionings.

\section{Reconciling mobilities and the place of education}

One of the aims of this paper is to bring to the fore work that has intentionally combined a 'place-based' (geographically embedded) perspective on education with an explicit awareness of the importance of mobilities in constituting learning. For simplicity, I have grouped this work into four key areas ('community', 'alternative', 'students' and 'capital'), beginning with a discussion of research that has sought to reconcile the role played by 'community' in education with the impact and influence of mobility. 


\section{i) Community and mobility}

There is a discordant relationship, within formal schooling, between the need and desire to champion (local) community and a prevailing tendency towards 'internationalisation' in its various guises. Nowhere is this tension more apparent than in the elite, independent school sector within England (amongst so-called public schools) (Brooks and Waters, 2014; Waters and Brooks, 2015). Recent research has highlighted a contradiction, wherein an imperative to emphasise local community engagement occurs to the detriment of acknowledging schools' actual internationalisation. Elite schools' external faces present a picture of extreme locality (including significant local community engagement) and relative isolation - what Waters and Brooks (2015) have termed 'function isolation'. Their web-sites depict various and multifaceted local involvements, which often include, for example, opening up school grounds and facilities to the wider community at certain times, partnerships with local state schools, visiting elderly residents in their homes, and other types of localised volunteering. However, many elite independent schools are also heavily involved in international activities of various kinds; the research identified, for example, that a number of schools have a high proportion (over 20 percent) of pupils with overseas nationality, many teach international curricula, overseas expeditions are common, and several (currently numbering 32 according to the Independent Schools' Council) have overseas or 'satellite' schools within Asia (Brooks and Waters, 2014). This tendency to downplay international linkages in favour of the 'local community' is intriguing not least because it is seemingly so exceptional, when a broader array of countries beyond the UK is taken into account - several studies undertaken in other national contexts have shown how schools are keen to display their international credentials (Aguiar and Nogueira, 2012; Campbell-Price and Duncan, 2014; Yoon, 2011). Internationalisation is seen as a valuable marker of difference and a 
source of institutional cultural capital in educational contexts outside the elite English school sector - perhaps related to the desire to create 'global citizens' or cosmopolitan subjects (Mitchell, 2003). Yet, within it internationalisation is assumed to detract from the inherent 'Englishness' these schools attempt to promulgate.

This tension between neighbourhood scales and internationalisation has also been observed for state (previously comprehensive) schools in Vancouver, Canada, where the introduction of 'mini-schools' has led to 'the decoupling of school and neighbourhood communities in the city' (Yoon, 2011, p. 265). Mini-schools are selective (elite) branches of 'regular' state schools, where pupils can receive a more targeted version of state education. They appeal particularly to immigrant populations, who would seem to value educational selection within the state sector (see also Waters, 2006b). Particularly interesting is Yoon's analysis of the notion of 'community' deployed within these schools and how it relates to the reality of 'globalisation':

'Compared to neighbourhood schools, mini schools have more frequent and extensive fieldtrips in order to build a sense of community amongst the students as well as to learn in different settings. Their field trip destinations vary from local to national and even global....Yet what has become an important characterization of these schools has been its emphasis on adaptations of the term 'community' (Yoon, 2011, p. 255).

In the example of mini-schools, then, alternative conceptions of community have been built what Yoon (2011) calls 'global city communities' - entities very distinct from neighbourhood communities of old. This complements the arguments proffered in Mitchell's (2003) paper on the trope of the 'strategic cosmopolitan,' wherein she described the ways in which schools in Canada, England and the United States were impacted by neoliberalisation, and the need to 
balance local and global policy agendas. These renderings of mobilities bring to the fore the juxtapositioning of state structures and the 'flows' associated with globalisation and cosmopolitanism. Here, international mobility is fundamental to constituting 'local' experiences of education.

At a different scale, Holdsworth (2009b) discusses the 'assumption of mutual exclusivity of local and student identities' within higher education in England (p. 225) - the term student, she argues, is frequently equated with middle-class and white individuals. What happens, Holdsworth asks, when increasing student immobility (the dual impact of widening participation measures and student fee increases) means that many students are also locals? The norm of limited (and even hostile) interactions between students and 'locals' influences the experiences of local students 'who have to maintain membership of both communities on a daily basis' (2009b, p. 235). Consequently, they can often feel as if they truly belong to neither community - feeling 'both 'out of place' but 'in place', (2009b, p. 235). The relationship between community and mobility has led in some cases, then, to community being redefined in relation to HE. In all of these examples, the term (local) community is put under pressure by, and held up in contradistinction to, different forms of mobility. Holdsworth's work is an excellent example of how students experience fixed and fluid subject positionings - how their (im)mobility is directly related to their student identity. It also implies the significant ripple effects of an individual's education upon their wider communities.

In a final example of community-mobility, Cheng (2015) has used the concept of biopolitics to conceptualise how private degree students attending a transnational college in Singapore engage with notions of (global/local) citizenship. Here, he argues that a biopolitical perspective needs also to attend to various structures, including class and gender, and the role played by concerns around social reproduction, in the decision making of these 
students. Here again, cosmopolitan mobilities are conceptualised alongside and in relation to local/national structures and immobilities.

\section{ii) Alternative spaces of education and mobilities}

As the name suggests, work on alternative education takes as its starting point an opposition to 'mainstream' schooling. This can and does include a challenge to the presumption that pre-tertiary education is associated with, and located within, a limited set of institutional spaces, specifically nurseries and schools. Space and place are often foregrounded in these analyses of alternative education and this work offers a distinctive alternate view to the institutional bias in educational research outlined above. It also exemplifies how concepts of place and mobilities may be combined in productive ways. One such example of this is found in research around homeschooling.

Kraftl (2012) notes that many parents of children who are home-schooled appeared to attach particular importance to specific landscapes and places within their discourses of mobile learning (Kraftl, 2012). Examples found in Kraftl's research include industrial and commercial landscapes and woodlands. The kitchen table also remains a popular trope, representing where the majority of learning in homeschooling actually takes place. Thus, it is interesting to observe that alternatives to formal schooling nevertheless often attach themselves rather sentimentally to specific sites and locations. This is also seen in Hanson Thiem's (2007) essay, describing how the homeschooling movement in the US has been predicated on the necessity of constructing the space of the home as a 'legitimate space for learning', the boundaries of which need to be defended (Ferrare and Apple, 2010, p. 212).

However, in Kraftl's (2012) work a great deal of homeschooling also takes place outside and beyond the space of the home and in fact involves 'a disparate array of connected local spaces' (2012, p. 437). He continues: 'spatial discourses, mobile practices and place- 
specific emotions and intimacies are central to [...] homeschooling' (p. 438). Homeschooling often literally involves learning 'on the move'. Thus, mobility is frequently integral to homeschooling - it is a fundamental part of the educational experience. Mobility is conceptualised in different ways. First and most conventionally, mobility involves movement (or travel is perhaps a more appropriate word) between identifiable places. The second refers to 'alternative pedagogical philosophies [which] share a commitment that physical movement (often play) [...] may lead to diverse forms of learning.' (p. 442). Here, physical movement is embodied and involves the production of particular education spaces (see McCormack, 2008), not just a movement through them. Learning is conceived as a 'spatial practice'. Sometimes, mobility in this sense was as simple as allowing children to run about, to go for a walk, or to travel in a car. There is a clear physicality to these movements and a close connection between physical activities and alternative forms of learning. Taken as a whole, work on alternative education decentres the institutional bias in educational research whilst also attending to the emplacement of learning. It allows us to reflect upon the relationship between alternative and mainstream, institution-based learning and fixed structures such as national curricula and public examinations. It has not, as yet, addressed sufficiently the 'ripple effects' implied by homeschooling and the (new?) subject positionings that homeschooling may engender.

\section{iii) Student mobilities}

As described in Holdsworth's (2009a, 2009b) work, there is often an assumption of mobility surrounding students - particularly for higher education. International students are especially viewed in this way - their inherent mobility is often assumed. International students are both physically mobile (moving between home and their country and institution of study) and they embody mobility (physical, cultural and social difference) within a 'host' 
community. They are regularly viewed as 'transnational' (Waters and Brooks, 2011) international mobility is their modus operandi. It is certainly the case that some research in this area has tended to valorise mobility, choice and individual agency over and above any structural constraints that student migrants might face. This is in keeping with a broader trend within the social sciences and humanities during the 1990s towards an uncritical celebration of mobility of various kinds (see Ley, 2010).

At different scales, the geographical literature has conversely shown how international students experience i) barriers to movement; and ii) fixed and fluid subject positionings; in relation to the nation-state (Marcu, 2015; Mavroudi and Warren, 2013; Warren and Mavroudi, 2011), the city (e.g. Collins, 2006; Park, 2010); and the university campus (Hopkins, 2011; Roy, 2014). Mavroudi and Warren (2013) describe how a 'juxtaposition exists between mobility and restriction for [international] students and academic staff' (p. 269). In their work, they have explored the impact of changes to UK immigration policy on the (in-) mobility of international students and academics:

'we stress the complex ways in which highly skilled migration, in the form of academic mobility, intersects with state control through embodied and emotional acts, outlining the need to contextualise and move beyond romanticised assumptions about academic mobility as being easy and overly positive (Robertson, 2010), and to take immigration policy into account' (p. 269).

They describe the emotive ways in which some international students respond to immigration policy changes, taking 'personally' increasing levels of restriction, and perceiving these as 'unwelcoming' and 'discouraging'. Similarly, in other research they have examined the impact that Biometric Residence Permits were having on non-EEA migrants, and the authors 
again concluded that they engendered feelings of unwelcomeness and 'difference' amongst immigrant groups (including international students) (Warren and Mavroudi, 2011).

In another example, Roy (2014) has considered the ways in which international students from India in Canada and the UK create and imagine 'home' within different spaces (domestic, university campus and city-wide). In her work, mobility and the place of education are examined together (they are, in fact, mutually constitutive). The intersection of 'home' and national policies are also discussed by Anderson (2012) in relation to New Zealand. Similarly, in his research on South Korean international students in Auckland, Collins (2008, p. 151; see also 2009) describes the 'transnational production of familiarity'. Here again, mobility and place are considered together, as inextricably linked components of international students' everyday experiences. Other research on international students emphasises their relative immobility (Fincher and Shaw, 2010; Hopkins, 2011). Fincher and Shaw (2009) demonstrate the tripartite institutional embeddedness of international students in Melbourne, Australia, in terms of their (segregated) housing, their physical location on the outskirts of the city, and the spaces in which they socialise.

In his work on critical geographies of the university campus, the mobility of Hopkins's (2011) research subjects is more assumed than actual; Hopkins considers how Muslim students are bound by discourses relating to their supposed interest in 'global issues'. This global consciousness is set against the immobility implied by the university campus. Again, mobility and groundedness in education are conceptualised together, as the following suggests:

'The narratives of Muslim students demonstrate the multiple and contradictory ways in which the university campus is experienced and draw attention to both the microgeographies of campus as well as the connections between global and national 
issues and how these influence and shape the ways in which the university campus is encountered' (Hopkins, 2011, p. 159).

Hopkins asserts his intention to contribute to 'theoretical and empirical perspectives' about the localised, everyday experiences of 'global processes' .... 'using the university campus as the container through which to explore these experiences' (Hopkins, 2011, p. 159). This is another example, then, of how mobility and emplacement are considered together as inextricably linked elements in a wider social puzzle.

What this section of the paper has aimed to demonstrate is that students are in different ways mobile but their mobility is variously constrained and shaped by national and societal discourses and policies.

\section{iv) Embedded institutional capital versus internationalisation}

The productive tension between mobility and emplacement is very apparent in work on the internationalisation of education. Education is seen as increasingly 'globalised' and 'globalising' as institutions, programmes, academics and students become ostensibly more mobile. Whilst this may have resulted in the reduction of international inequalities around access to education, the opposite has in fact occurred - globalisation has elicited increasing differentiation in education and the consolidation of academic 'power' within particular countries and institutions (Findlay et al., 2012; Lewis, 2011). International students continue to be attracted to particular regions of the world, countries, and institutions within those countries. Large scale flows of students from 'non-English speaking' to 'English speaking' regions of the world are well documented (Brooks and Waters, 2011). And although we now know that the reality of international student mobilities is in fact far more complex than this 
rendering would suggest (with the growth, for example, of within-Asia regional educational mobilities and attempts by non-native-English-speaking countries to attract 'Englishspeaking' clientele), the United States and the United Kingdom continue to attract by far the greatest share of international students world wide - of the 4.5 million students enrolled in tertiary education outside their countries of citizenship in $2012,16 \%$ of this share went to the United States whilst 13\% went to the UK (OECD, 2014). Conversely (and highlighting some revealing geographical disparities), only $2 \%$ of UK tertiary students were enrolled abroad (in 2012), whilst the number for the US was negligible (OECD, 2014). Particular regions and countries are over- and under-represented on the global map of student mobilities (53\% of all foreign students in 2012 came from countries in Asia) (ibid.).

Geographical scholarship on student mobilities has suggested why these patterns persist (despite some gradual changes and shifts). Jöns and Hoyler (2013), for example, examine the ascendency of world university rankings in public debates around higher education. They illustrate the role of global rankings in the production of geographies of education. These geographies include, for example, the (embedded) role that universities play in regional economic development. They also include the persistence of certain 'academic hegemonies': in other words, 'distinctive but shifting asymmetries between centers that dominate academic discourse and those with peripheral standing' (2013, p. 47). They make a number of striking observations about the 'partial' perspectives offered by the ranking metrics employed by Shanghai Jiao Tong University in China (since 2003) and the Times Higher World University Ranking in the UK (since 2004). There is an overlap of 138 universities in the top 200 of the two rankings, wherein universities in North America and Europe are overwhelmingly dominant. They write, in relation to this: 
'the highly uneven geographies of higher education that emerge from the analysis mark particular nodes in the global circulation of knowledge and expertise, namely those that conform best to Anglo-American publication cultures in the highly expensive technosciences that facilitated American hegemony in the second half of the $20^{\text {th }}$ century and are seen as drivers of economic growth (Kenway et al., 2004; Paasi, 2005). The resulting geographies display striking disparities between the global North and South as well as between the economically prospering regions in North America, Europe, East Asia and Australia and large parts of South America, Africa and Asia that are either economically disadvantaged and/or dominated by other languages than English' (Jöns and Hoyler, 2013, p. 56).

What their analysis unequivocally shows is that whilst league tables may influence the global circulation of students, particular regions, countries and universities within those countries continue to possess a disproportionate share of institutional cultural capital, reflecting at heart long-standing material inequalities between those regions and countries.

Findlay et al. (2012) make a similar point about institutional 'cultural capital.' Their paper explores 'the meaning of seeking a 'world-class' university, arguing that the social construction of an outstanding international university has resulted in a global hierarchy of institutions' (p. 128). They enlist Bourdieu's theory of capital to consider the social advantages that accrue to internationally mobile students through their education (see also Waters, 2006a). Mobility is integral to the cultural capital acquired through their educational experiences, and yet so equally is emplacement (within particular national and institutional contexts). An international education also indicates a propensity towards future mobility - 'a 'world-class' education for some is embedded in a mobility culture' (Findlay et al., 2012, p. 128) that ascribes value to 'international career trajectories' (ibid.). 
These patterns in the differentiation of higher education globally, Findlay et al. (2012) predict, are likely to increase over time 'in relation to socially constructed 'reputations' and increasingly sophisticated authenticity claims about what constitutes a 'world-class' university' (p. 128). Thus, the mobility of students and the embeddedness of global reputations are inextricably linked, relational phenomena.

Madge et al. (2009) provide a rare postcolonial analysis of international student mobilities (see also Matthews and Sidhu, 2005), which also emphasises the fundamental links between mobility and emplacement in education. They call for a more 'engaged pegagogy' within UK HEIs involved with the recruitment and teaching of international students, which would include an awareness of the forms of 'interdependence' and 'mutuality' inscribed within the relationship between students and their institutions. HEIs also have a duty of care and responsibility for international students - something that is not always acknowledged and acted upon.

In other work, the embeddness of global institutionalised cultural capital has been discussed. Sin, (2009), for example, has focussed on international students from Malaysia in the UK, and emphasised these students' preference for a specifically British educational experience (c.f. Waters and Leung, 2013, on students in Hong Kong). The role of English as a 'global language' is another enduring theme - the desire for English continues to drive a majority of international student migrations (what Chew, 2010, describes as 'linguistic migration'). Park and Bae (2009) have discussed the significance of English in fuelling migration for education in South Korea. They make the following key points: that there exists a belief that 'good English' is crucial for a successful career; that 'exposure' to English within 'an English-speaking environment' is a necessary prerequisite for good English skills; and that this level of exposure can only be achieved by living overseas. For the purposes of 
this paper, however, most interesting is their insistence on the value of 'specific geographical locations' for achieving this goal, as the following quotation indicates:

'the belief that competence in English conducive to social mobility can only be obtained at specific geographical locations, namely the English speaking countries of the West...In other words, jogi yuhak [early study abroad] must be seen as driven by globally dominant ideologies of English that constitute highly specific views of language, place and social space' (Park and Bae, 2009, p. 368).

Again, this work attempts to reconcile 'the global' and international forms of mobility with 'local' embeddeness through education.

As education becomes more internationalised and transnationalised, then, so the location of education (metaphorically in various global hierarchies and literally in terms of where on the globe institutions are located) is more salient than ever. Distinctive and significant geographies of cultural and social capital, tied to particular educational experiences and academic credentials, exist (Waters, 2006a). Intriguingly, this is not just occurring at the level of higher education, nor only in relation to elite private education (as one might expect). As papers by Yoon (2011) on mini-schools in Canada and Mitchell (2003) on national education systems in the USA, Canada and the UK, have shown, state (hitherto comprehensive) schools are engaging with discourses of global excellence and international competitiveness. Local geographical differences (inequalities) become consequently increasingly entrenched.

\section{Discussion and conclusions}

This paper engages with debates, prevalent over the past decade, around geographies of education. Geographers are increasingly grappling with themes related to education and 
learning and, at the same time, scholars outside the discipline of geography are embracing what has been described as a 'spatial turn' in educational theory. There are changes in the ways in which education is conceptualised, more broadly, that are pertinent context to this discussion. First is the ever more pivotal role that education plays in structuring societies around the world, and in shaping life chances. As investment in education increases almost universally, so there has also been a societal shift in understandings of what constitutes education: when learning occurs (discourses of 'life-long' learning and 'continuing' education are more and more apparent and widespread), and with that where learning occurs too (beyond the class room and into work spaces and (via distance learning) domestic space see Brooks et al., 2012). It also acknowledges the fact that education is no longer confined to national concerns, but is ever more international in its parameters.

Examining these conceptual developments in detail has been beyond the scope of this paper. Instead, it has had a particular aim - to highlight an emergent tension within work around geographies of education between the emplacement of learning, and a favouring of mobilities (both conceptually and empirically) in research and writing; and to tease out the exciting implications of this tension for advancing research agendas.

There is a long tradition of ascribing distinctive spatial boundaries to learning. Much scholarship to date has focussed on particular institutional environments as containers of education, namely schools and universities. Within these spaces, smaller scale geographies have been examined, including social interactions within playgrounds, lunch halls and halls of residency. Clearly, it can be useful to view education in this way; as noted in the discussion above, particular institutional spaces remain important for learning and also provide a helpful way of delimiting research parameters. However, I have also suggested that there are some limitations attendant with this perspective, and that work on mobilities in human geography and sociology (the 'mobilities turn') has recently impacted research on 
education in fruitful ways (specifically in relation to what it has to say about ripple effects, structures and subject positionings). I identified four approximate and overlapping 'areas' of research that has adopted a mobilities 'lens': i) community and mobility; ii) 'alternative' spaces of education; iii) student mobilities; and iv) embedded institutional capital and internationalisation. Work on community and mobility has generally considered how mobilities over distance are impacting upon concepts of 'the local'. A small number of divergent examples were considered here, but they showed how community is often synonymous with immobility (emplacement) and set in opposition to the assumed mobility of students. Second, the paper considered briefly writing on alternative forms of education and focused on homeschooling as an example of an area of research where both mobility and emplacement are deemed integral to learning. Third, geographers have examined the (im)mobility of students - the paper looked at the ways in which contemporary students are mobile (at various scales) as well as the ways in which mobility is assumed to be fundamental to the student experience. Fourth and finally, the paper considered how international education remains conterminously wedded to particular national and institutional contexts, as shown in the prevailing global hierarchy of universities and dominant and persistent patterns of student migration wedded to the accumulation of place-specific cultural capital (Findlay et al., 2012).

The broad aim of this paper has been to consider the ways in which the concept of mobilities can enhance our understanding of geographies of education and, in so doing, progress debates. It is obviously not an exhaustive account of work around mobilities and education in geography - some salient areas not touched upon in any depth include MOOCs and transnational education (TNE) and research on education across the lifecourse, including, for example, work on very young children and postdoctoral students. Raghuram's (2013) recent attempt to destabilise the category of 'international student', by recognising the fact 
that many different types of migrant also undertake learning, is very pertinent. Neither has the paper dealt with the methodological implications of applying a mobilities perspective to studies of education and learning (see Collins, 2012, for an early attempt at this). However, bearing in mind these constraints, the paper has addressed the question: how does a 'mobilities' perspective therefore animate fresh approaches to understanding education? I propose three particular ways here. First, there has been a tendency in the academic literature on education either to prioritise various structures (such as class or state structures) or to (over) emphasise student agency (individualisation). The concept of mobilities emphasises relationality - the need to view education in the round. Second and related, a mobilities perspective usually introduces a degree of geographical sensitivity and ensures an outward looking view of education that takes into account its various ripple effects. Third, mobilities emphasises the spatial contingency of student identities, as Holdsworth (2009a \&2009b) and Ghosh and Wang (2003) so ably demonstrate. It is my belief that through developing these understandings of the relationship between mobilities and place, geographers can have a significant impact upon debates in diverse areas of study around education and learning.

\section{$\underline{\text { Acknowledgements }}$}

An early version of this paper was presented at the University of Surrey conference 'Education and Learning: Sociological Perspectives', September 2013. I would like to thank Rachel Brooks for inviting me and for all our subsequent discussions, and audience members for providing valuable feedback on my presentation. Two anonymous referees, Pauline McGuirk and Noel Castree have provided helpful and constructive feedback on earlier drafts, for which I am extremely grateful.

\section{$\underline{\text { References }}$}

Abelmann, N. (2009) The Intimate University: Korean American Students and the Problems of Segregation Duke University Press. 
Ackers, L. and Gill, B. (2008) Moving People and Knowledge: Scientific Mobility in an Enlarging Europe Edward Elgar, London.

Adey, P. (2006) If mobility is everything then it is nothing: towards a relational politics of (im)mobilities Mobilities 1 (1), 75-94.

Adey, P. (2010) Aerial Life: Spaces, Mobilities, Affects. Oxford: Wiley-Blackwell.

Aguiar, A. and Nogueira, M. (2012) Internationalisation strategies of Brazilian private schools International Studies in Sociology of Education 22 (4), 353 - 68.

Alberts, H. and Hazen, H. (2005) 'There are always two voices....': international students' intentions to stay in the United States or return to their home countries International Migration 43 (3), 131-154.

Alberts, H. and Hazen, H. eds. (2013): International Students and Scholars in the United States: Coming from Abroad, Palgrave Macmillan, New York

Anderson, V. (2012) 'Homes' and being 'at home' in New Zealand: women's place-making in internationalised higher education Gender, Place \& Culture: A Journal of Feminist Geography, 19 (3): $327-343$.

Andersson, J., Sadgrove, J. and Valentine, G. (2012) Consuming Campus: Geographies of Encounter at a British University. Social and Cultural Geography13 (5): 501-515 Apple, M. W., Kenway, J. and Singh, M. (2005) Globalizing education: policies, pedagogies and politics Peter Lang Publishing, New York.

Ball, S. J., Bowe, R. and Gerwitz, S. (1995) Circuits of schooling: a sociological exploration of parental choice of school in social-class contexts Sociological Review 43, 52 - 78.

Ball, S. (2016) Following policy: networks, network ethnography and education policy mobilities Journal of Education Policy. Online early. 
Barker, J., Alldred, P., Watts, M. and Dodman, H. (2010), Pupils or prisoners? Institutional geographies and internal exclusion in UK secondary schools. Area, 42, 378-386.

Bourdieu, P. (1986) The forms of capital. In Handbook of Theory and Research for the Sociology of Education. J. G. Richardson (ed.). NY: Greenwood Press, 241 - 258.

Brooks, R. and Waters, J. (2011) Student Mobilities, Migration and the Internationalization of Higher Education Basingstoke: Palgrave Macmillan.

Brooks R.M., Waters, J.L. (2014) The hidden internationalism of elite English schools Sociology, Advance online publication.

Brooks, R. and Waters, J. (Forthcoming) Education, Space and Place, under contract with Routledge.

Brooks R., Fuller A. and Waters J. (2012) Changing Spaces of Education. New perspectives on the nature of learning. London: Routledge

Brooks R.M., Byford K., Sela K. (2015) 'Students' unions, consumerism and the neo-liberal university'. British Journal of Sociology of Education Online early.

Butler T. and Hamnett C. (2010) 'You take what you are given': the limits to parental choice in education in east London Environment and Planning A 42(10), 2431 - 2450.

Campbell-Price, M., Duncan, T. (2014) Experiencing the (different) everyday on an international school-led trip: a New Zealand example. In: Presentation to the RGS-IBG Annual Conference, 26-29 August 2014, London.

Cheng, Y.E. (2015) Biopolitical geographies of student life: private higher education and citizenship life-making in Singapore. Annals of the Association of American Geographers, 105(5): 1078-1093. 
Chew, P. G. (2010) 'Linguistic capital, study mothers and the transnational family in Singapore' in V. Vaish (ed.) Globalization of Language and Culture in Asia, 82 - 105.

Christie, H (2007) Higher education and spatial (im)mobility: non-traditional students and living at home Environment and Planning A 39, 2445 - 2463.

Collins, D. and Coleman, T. (2008) Social geographies of education: looking within and beyond, school boundaries Geography Compass 2(1), 281 - 299.

Collins, F.L. (2006) Making Asian students, making students Asian: the racialisation of export education in Auckland, New Zealand Asia Pacific Viewpoint 47 (2), 217-234. Collins F.L. (2008) Of kimchi and coffee: globalisation, transnationalism and familiarity in culinary consumption, Social and Cultural Geography 9 (2), 151-169.

Collins, F.L (2010) Negotiating Un/Familiar Embodiments: investigating the corporeal dimensions of South Korean international student mobilities in Auckland, New Zealand Population, Space and Place 16 (1), 51-62.

Collins, F. L. (2012), Researching mobility and emplacement: examining transience and transnationality in international student lives Area, 44, 296-304.

Collins, F. L., Sidhu, R., Lewis, N., \& Yeoh, B. S. A. (2014). Mobility and desire: International students and Asian regionalism in aspirational Singapore. Discourse: Studies in the Cultural Politics of Education, 35 (5), 661-676

Cook, V. A., and Hemming, P. J. (2011) Education spaces: embodied dimensions and dynamics Social and Cultural Geography 12 (1), 1 - 8.

Cresswell T (2006) On the Move: Mobility in the Modern Western World New York, London: Routledge. 
Ferrare, J. and Apple, M. (2010) Spatializing critical education: progress and cautions Critical Studies in Education 51 (2), 209 - 221.

Ferrari E., Green M. A. (2013) Travel to school and housing markets: a case study of Sheffield, England Environment and Planning A 45(11), 2771 - 2788.

Fincher R, and Shaw K. (2009) The unintended segregation of transnational students in central Melbourne Environment and Planning A 41 (8), 1884-1902.

Findlay, A., King, R. Smith, F. and A. Geddes, R. Skeldon (2012) 'World class? An investigation of globalisation, difference and international student mobility' Transactions of the Institute of British Geographers 37 (1), 118 - 131.

Findlay, A., King, R., Stam, A. and E. Ruiz-Gelices (2006) Ever reluctant Europeans: the changing geographies of UK students studying and working abroad. European Urban and Regional Studies 13, $291-318$.

Geddie, K. (2012) Constructing transnational higher education spaces: international branch campus development in the United Arab Emirates, in Brooks R., Fuller A. and Waters J. (2012) Changing Spaces of Education. New perspectives on the nature of learning. London: Routledge, pp. $39-58$.

Geddie, K. (2014), Policy mobilities in the race for talent: competitive state strategies in international student mobility. Transactions of the Institute of British Geographers

Ghosh, S. and Wang, L. (2003) 'Transnationalism and identity: a tale of two faces and multiple lives', Canadian Geographer/ Le Géographe canadien, 47 (3): 269-282.

Gibson, A. and Asthana, A. (1998a) School pupils and examination results: contextualising school 'performance' British Educational Research Journal 24, 269 283. 
Gibson, A and Asthana, S. (1998b) School performance, school effectiveness and the 1997 White Paper Oxford Review of Education 24, 195 - 211.

Goffman, E. (1961) Asylums: Essays on the Social Situation of Mental Patients and Other Inmates Berkeley: Penguin Books.

Gulson, K. and Symes, C. (eds) (2007) Spatial Theories of Education. Policy and Geography Matters New York, Routledge.

Hanson Thiem, C. (2007) The spatial politics of educational privitization. In Gulson, K. and Symes, C. (eds) Spatial Theories of Education. Policy and Geography Matters New York, Routledge.

Hanson Thiem, C. (2009) Thinking through education: the geographies of contemporary educational restructuring Progress in Human Geography 33 (2), 154 - 173.

Harris R, 2012, "Local indices of segregation with application to social segregation between London's secondary schools, 2003 - 08/09" Environment and Planning A 44(3), 669 - 687.

Herbert, D. and Thomas, C. (1998) School, performance, league tables and social geography Applied Geography 18 (3), 199 - 223.

Hinton, D. (2011) 'Wales is my home': higher education aspirations and student mobilities in Wales Children's Geographies 9 (1), 23 - 34.

Holdsworth, C. (2009a) 'Going away to uni': mobility, modernity, and independence of English higher education students' Environment and Planning A 41, 1849 - 1864.

Holdsworth C. (2009b) Between Two Worlds: Local Students in Higher Education and 'Scouse'/Student Identities Population, Space and Place 15(3), 225-237.

Holdsworth C. 2013. Family and Intimate Mobilities. Basingstoke: Palgrave Macmillan. 
Holloway, S. L. and Jöns, H. (2012), Geographies of education and learning. Transactions of the Institute of British Geographers, 37, 482-488.

Holloway, S., Hubbard, P., Jöns, H., Pimlott-Wilson, H. (2010) Geographies of education and the significance of children, youth and families Progress in Human Geography 34, 583 600.

Holt, L. (2003) (Dis)abling children in primary school micro-spaces: geographies of inclusion and exclusion Health and Place 9 (2), 119 - 128.

Holt, L. (2007) Children's sociospatial (re)production of disability within primary school playgrounds Environment and Planning D: Society and Space 25(5), 783 - 802.

Hopkins, P. (2011) Towards critical geographies of the university campus: understanding the contested experiences of Muslim students Transactions of the Institute of British Geographers 36, 157-169.

Jeffrey, C. (2010) Timepass: youth, class and time in India. American Ethnologist, 37(3), $465-481$.

Jeffrey, C. (2008) Generation nowhere: rethinking youth through the lens of unemployed young men. Progress in Human Geography, 32(6), 739-758.

Johnston R, Wilson D, Burgess S, 2007, "Ethnic segregation and educational performance at secondary school in Bradford and Leicester" Environment and Planning A 39(3), 609 - 629

Jöns, H. and Hoyler, M. (2013) Global geographies of higher education: The perspective of world university rankings Geoforum 46, $45-59$.

Jöns, H. (2007) Transnational mobility and the spaces of knowledge production: a comparison of global patterns, motivations and collaborations in different academic fields Social Geography, 2, 97-114. 
Kenway, J., Bullen, E., Robb, S. (2004) The knowledge economy, the techno-preneur and the problematic future of the university Policy Futures in Education, 2 (2), 330-349

King, R. and Ruiz-Gelices, E. (2003) International student migration and the European 'yearabroad': effects on European identity and subsequent migration behaviour International Journal of Population Geography 9 (3), 229-252.

King, R., Findlay, A., Aherns, J. and Dunne, M. (2011) Reproducing advantage: the perspective of English school leavers on studying abroad Globalisation, Societies and Education 9 (2), $161-181$.

Kraftl , P. (2006) Building an idea: the material construction of an ideal childhood. Transactions of the Institute of British Geographers 31, 488 - 504.

Kraftl, P. (2013a) Towards geographies of 'alternative' education: a case study of UK home schooling families Transactions of the Institute of British Geographers, 38, 436-450.

Kraftl, P. (2013b) Geographies of Alternative Education: Diverse learning spaces for children and young people Bristol: Policy Press.

Kraftl, P. (2015) Alter-Childhoods: biopolitics and childhoods in alternative education spaces Annals of the Association of American Geographers, 105 (1), 219 - 237.

Kraftl, P., Christensen, P., Horton, J. and Hadfield-Hill, S. (2013) Living on a Building Site: Young People's Experiences of Emerging 'Sustainable Communities' in England Geoforum, 50, 191-199.

Kraftl, P. (2012) Utopian Promise or Burdensome Responsibility? A Critical Analysis of the UK Government's Building Schools for the Future Policy, Antipode 44, 847-870 
Lee, S. and Brinton, M. (1996) Elite education and social capital: the case of South Korea Sociology of Education 69 (3), 177 - 192.

Leung, M. and Waters, J. (2013) Transnational higher education for capacity development? An analysis of British degree programmes in Hong Kong' Globalisation, Education and Society 11 (4): 479-497.

Leung, M. W. H. (2013) 'Read ten thousand books, walk ten thousand miles': geographical mobility and capital accumulation among Chinese scholars. Transactions of the Institute of British Geographers, 38, 311-324.

Lewis, N. (2011) Political projects and micro-practices of globalising education: building an international education industry in New Zealand Globalisation, Societies and Education 9 (2), $225-246$.

Ley, D. (2010) Millionaire Migrants: Trans-Pacific Lifelines RGS-IBG Book Series, Oxford, Wiley-Blackwell.

Madge, C., Raghuram, P., and Noxolo, P. (2014) Conceptualizing international education From international student to international study, Progress in Human Geography, Advance Online Publication.

Madge, C., Raghuram, P., and Noxolo, P. (2009) Engaged pedagogy and responsibility: a postcolonial analysis of international students Geoforum, 40, 34-45.

Marcu, S. (2015) Uneven mobility experiences: Life-strategy expectations among Eastern European undergraduate students in the UK and Spain Geoforum 58, 68 - 75.

Matthews, J. and Sidhu, R. (2005) Desperately seeking the global subject: international education, citizenship and cosmopolitanism Globalisation, Societies and Education, 3 (1), 49-66. 
Mavroudi, E. and Warren, A. (2013) Highly skilled migration and the negotiation of immigration policy: non-EEA postgraduate students and academic staff at English universities, Geoforum 44, 261-270

McCann, E. (2011) Urban policy mobilities and global circuits of knowledge: toward a research agenda Annals of the Association of American Geographers, 101 (1), 107-130. McCormack, D. P. (2008), Geographies for Moving Bodies: Thinking, Dancing, Spaces. Geography Compass, 2, 1822-1836.

Mitchell, K. (2003) Educating the national citizen in neoliberal times: from the multicultural self to the strategic cosmopolitan Transactions of the Institute of British Geographers $28,387-403$.

Murphy-Lejeune, E. (2004) Student Mobility and Narrative in Europe: The New Strangers Routledge: London.

Nieuwenhuis J., Hooimeijer P., van Dorsselaer S. and Vollebergh W. (2013) Neighbourhood effects on school achievement: the mediating effect of parenting and problematic behaviour? Environment and Planning A 45 (9), 2135 - 2153.

OECD (2014) Education at a Glance Paris, OECD Publications.

Park, H. (2010) The stranger that is welcomed: female foreign students from Asia, the English language industry, and the ambivalence of 'Asia rising' in British Columbia, Canada Gender, Place and Culture 17 (3), 337-355.

Park, J. and Bae, S. (2009) Language ideologies in educational migration: Korean jogi yuhak families in Singapore Linguistics and Education 20, 366 - 377.

Paasi, A. (2005) Globalisation, academic capitalism, and the uneven geographies of international journal publishing spaces Environment and Planning A, 37 (5), 769-789. 
Peck, J. (2011) Geographies of policy. From transfer-diffusion to mobility-mutation Progress in Human Geography 35 (6), 773-797.

Pike, J. and Colquhoun, D. (2012) Lunchtime lock-in: territorialisation and UK school meals policies. In: Kraftl, P., Horton, J., Tucker, F. (Eds.), Critical Geographies of Childhood and Youth: Contemporary Policy and Practice. Policy Press, Bristol, $133-148$.

Pooley C., Whyatt D., Walker M., Davies G., Coulton P., Bamford W. (2010) Understanding the school journey: integrating data on travel and environment Environment and Planning A 42(4), $948-965$.

Philo, C. and Parr, H. (2000) Institutional geographies: introductory remarks. Geoforum $31(4), 513-521$.

Raghuram, P. (2013) Theorising the spaces of student migration. Population Space and Place $19(2), 138-154$.

Reh, S., Rabenstein, K and Fritzsche, B. (2011) Learning spaces without boundaries? Territories, power and how schools regulate learning Social and Cultural Geography, 12 (1), $83-98$.

Robertson, S. (2011) Student switchers and the regulation of residency: the interface of the individual and Australia's immigration regime Population, Space and Place 17, 103 - 115.

Roy, S. (2014) Experiencing 'Home' in the City, University and Dwelling: Everyday Geographies of Indian Students in London and Toronto. Unpublished PhD Thesis, Queen Mary, University of London.

Rizvi, F. and Lingard, B. (2010) Globalizing Education Policy Oxford: Routledge. 
Sheller, M. and Urry, J. (2006) The New Mobilities Paradigm, Environment and Planning A $38(2), 207-226$.

Sidhu, R. (2006) Universities and Globalization. To market, to market. New Jersey, Laurence Erlbaum Associates Ltd.

Sin, I. L. (2009) The aspiration for social distinction: Malaysian students in a British university Studies in Higher Education 34 (3), 285-299.

Sykes B. and Kuyper H. (2009) Neighbourhood effects on youth educational achievement in the Netherlands: can effects be identified and do they vary by student background characteristics? Environment and Planning A 41(10), 2417 - 2436.

Taylor, C. (2001) The geography of choice and diversity in the 'new' secondary education market of England Area 33, 368 - 381 .

Taylor, C. (2002) Geography of the 'New' Education Market. Secondary School Choice in England and Wales Aldershot, Ashgate.

Thieme, S. (2014) An international degree, social ties and return: when international graduates make a career back home in Kyrgyzstan. Internationales Asienforum/International Quarterly for Asian Studies, 45(1-2), 113-128.

Thomson, S. (2005) 'Territorialising' the primary school playground: deconstructing the geography of playtime Children's Geographies 3 (1), 63 - 78.

Turner, S. and Manderson, D. (2007) Socialisation in a space of law: student performativity at 'Coffee House' in a university law faculty Environment and Planning D: Society and Space 25, $761-782$.

Urry J (2000) Sociology Beyond Societies: Mobilities for the Twenty-First Century London, New York: Routledge. 
Walton-Roberts, M., (2015) "Femininity, mobility and family fears: Indian international student migration and transnational parental control." Journal of Cultural Geography 32,1: $68-82$.

Warren, A. and Mavroudi, E. (2011) Managing Surveillance? The Impact of Biometric Residence Permits on UK Migrants, Journal of Ethnic and Migration Studies, 37(9), 14951511.

Warrington, M. (2005) Mirage in the desert? Access to educational opportunities in an area of social exclusion Antipode 37, 766ology Beyond Societies: Mobilities for the Twenty-First Century. London, Routledge.

$-816$.

Waters, J. and Brooks, R. (2015) 'The magical operations of separation': English elite schools' on-line geographies, internationalisation and functional isolation Geoforum 58, 86 94.

Waters and Leung (2013) 'Young people and the reproduction of disadvantage through transnational higher education in Hong Kong' Sociological Research On-line, 17 (3).

Waters, J. L. (2006a) Geographies of cultural capital: education, international migration and family strategies between Hong Kong and Canada Transactions of the Institute of British Geographers 31 (2), $179-192$.

Waters, J.L. (2006b) Emergent geographies of international education and social exclusion Antipode, 38(5), 1046-1068.

Waters, J. L. (2007) 'Roundabout routes and sanctuary schools': the role of situated educational practices and habitus in the creation of transnational professionals' Global Networks 7 (4), $477-497$. 
Waters, J. L. (2008) Education, Migration and Cultural Capital in the Chinese Diaspora: Transnational Students between Hong Kong and Canada New York, Cambria Press.

Waters, J. L. (2009) 'Transnational geographies of academic distinction: the role of social capital in the recognition and evaluation of 'overseas' credentials' Globalisation, Societies and Education 7(2), $113-129$.

Wilson E. J., Marshall J., Wilson R. and Krizek K. J. (2010) By foot, bus or car: children's school travel and school choice policy Environment and Planning A 42(9), 2168 - 2185.

Williams, A. M. (2007), Listen to Me, Learn with Me: International Migration and Knowledge Transfer. British Journal of Industrial Relations, 45, 361-382.

Yoon, E. (2011) Mini-schools: the new global city communities of Vancouver Discourse: Studies in the Cultural Politics of Education 32 (2), 253 - 268. 